\title{
Penerapan Metode Simple Additive Weighting(SAW) Dalam Pemilihan Kacamata
}

\author{
Application of the Simple Additive Weighting (SAW) Method in the Selection of Glasses
}

\author{
Dini Ridha Dwiki Putri ${ }^{1}$, Muhammad Reza Fahlevi ${ }^{2}$ \\ ${ }^{1}$ Jurusan Rekayasa Perangkat Lunak, Universitas Potensi Utama \\ ${ }^{2}$ Jurusan Rekayasa Sistem Komputer, Universitas Potensi Utama \\ Jalan KL Yos Sudarso Km 6.5 No. 3A Tanjung Mulia, Medan \\ e-mail:*11putrydiny11@gmail.com, 22ezafahlevi72@gmail.com
}

\begin{abstract}
Abstrak
Kacamata adalah suatu frame yang menahan dua lensa kaca atau mika yang sangat tipis berguna untuk melindungi, menormalkan, dan mempertajam penglihatan serta digunakan untuk membantu mata mencapai penglihatan secara normal. Sistem Pendukung Keputusan dapat membantu atau merekomendasi kacamata yang sesuai dengan keinginan pembeli dan memberikan kenyamanan dalam penglihatan. Metode Simple Additive Weighting (SAW) adalah metode yang digunakan pada pemilihan kacamata ini. Metode Simple Additive Weighting (SAW) ini digunakan untuk mencari alternatif terbaik dengan cara menganalisa dan menyeleksi beberapa alternatif dari kacamata dengan kriteria lensa, warna frame, harga, dan merek. Implementasi penerapan metode SAW ini menggunakan bahasa pemrograman PHP dan database MySQL yang menyatakan bahwa alternatif terbaik adalah alternatif yang memiliki nilai ranking lebih besar, sehingga alternatif terbaik adalah alternatif yang memiliki persentasi terbesar yaitu Optika Lunet dengan nilai 95\%.
\end{abstract}

Kata kunci-Kacamata, Sistem Pendukung Keputusan, Metode Simple Additive Weighting (SAW).

\begin{abstract}
Glasses are a frame that holds two very thin glass or mica lenses that are useful for protecting, normalizing, and sharpening vision and are used to help the eye achieve normal vision. Decision Support Systems can help or recommend glasses that match the buyer's wishes and provide comfort in vision. The Simple Additive Weighting (SAW) method is the method used in the selection of these glasses. The Simple Additive Weighting (SAW) method is used to find the best alternative by analyzing and selecting several alternatives of glasses with the criteria of lens, frame color, price, and brand. The implementation of the SAW method uses the PHP programming language and MySQL database which states that the best alternative is the alternative that has a higher ranking value, so that the best alternative is the alternative that has the largest percentage, namely Optika Lunet with a value of $95 \%$.
\end{abstract}

Keywords—Glasses, Decision Support Systems, Simple Additive Weighting (SAW) Method.

\section{PENDAHULUAN}

Mata adalah organ penglihatan pada tubuh yang berfungsi mendeteksi cahaya dan yang mengubahnya menjadi impuls elektrokimia pada sel saraf. Kondisi mata akan sakit dan tidak nyaman jika melihat cahaya yang terlalu terang, terkena debu, atau serangga. Kacamata digunakan untuk melindungi mata dari masalah tersebut dan berfungsi meningkatkan ketajaman penglihatan dan membantu sistem kerja pada mata. 
Kacamata merupakan sebuah alat bantu penglihatan bagi seseorang yang memiliki gangguan pada indera penglihatan. Semakin pesatnya perkembangan teknologi khususnya bendabenda elektronik yang menggunakan layar monitor, setiap orang dituntut untuk mampu mengikuti perkembangan tersebut, seringnya melihat layar monitor, terkena paparan radiasi dari layar monitor baik komputer, telepon seluler, maupun benda elektronik lainnya maka semakin lama akan berpengaruh terhadap daya penglihatan seseorang. Penjual kacamata sering kali mengalami kesulitan dalam memilih lensa yang sesuai dengan kebutuhan dan keinginan konsumen. Hal ini disebabkan karena konsumen kurang mengetahui macam-macam lensa yang ada, sehingga konsumen kurang leluasa memilih lensa yang sesuai dengan keinginan dan kebutuhan mereka dan hanya tergantung pada pihak Optik saja.

Sistem Pendukung Keputusan adalah sebuah alternatif solusi atau alternatif tindakan dari sejumlah alternatif solusi dan tindakan guna menyelesaikan suatu masalah, sehingga masalah tersebut dapat diselesaikan secara efektif dan efisien. Sistem Pendukung Keputusan berfungsi untuk beberapa hal antara lain, sebagai pemahaman secara komprehensif terhadap masalah, sebagai pemberian kerangka berfikir secara sistematis, dapat membimbing dalam penerapan teknik-teknik pengambilan keputusan, dan meningkatkan kualitas suatu keputusan.

Sistem Pendukung Keputusan memiliki beberapa metode, Metode tersebut digunakan untuk mengambil keputusan dalam pertimbangkan banyak hal untuk itu digunakanlah metode agar dapat mengambil keputusan dengan tepat atau yang sering disebut Multi Attribute Decision Making (MADM) yaitu proses pengambilan keputusan terhadap sebuah masalah yang memiliki beberapa atribut penting untuk dipertimbangkan dan mencari alternatif optimal dari sejumlah alternatif dengan kriteria tertentu.

Salah satu contoh dalam menggunakan MADM adalah cara pemilihan kacamata yang baik untuk penglihatan dengan menggunakan metode Simple Additive Weighting (SAW). Simple Additive Weighting (SAW) adalah metode pengambilan keputusan dengan cara menormalisasi matriks ke suatu sekala yang dapat di pertimbangkan dengan data-data yang sudah di kumpulkan lalu dibuatkan kriteria penilaian berdasarkan data-data tersebut.

Dengan menerapkan metode Simple Additive Weighting(SAW) hasil yang didapatkan akan terlihat jelas, dengan begitu dapat ditentukan dengan optimal kacamata yang harus dipilih berdasarkan kriteria lensa, warna frame, harga, dan merek. Oleh karena itu penggunaan metode ini dalam memilih kacamata sangat berguna untuk pembeli.

\section{METODE PENELITIAN}

Penelitian ini bertujuan untuk merancang sistem dalam pemilihan kacamata dengan menerapkan metode Simple Additive Weighting (SAW) sebagai analisa metodenya. Penelitian ini berguna untuk dapat memberikan rekomendasi dalam memilih kacamata sesuai dengan kriteria yang diinginkan pembeli dan memudahkan pihak optik merekomendasikan lensa yang sesuai dengan mata pembeli.

Data input berupa lensa, warna frame, harga, dan merek dan output berupa alternatif kacamata yang memiliki nilai preferensi terbesar berdasarkan perhitungan menggunakan metode Simple Additive Weighting (SAW) dengan menggunakan bobot masing-masing kriteria. Penentuan kriteria dan alternatif berdasarkan observasi langsung ke optik.

Data tersebut akan dianalisa dengan menggunakan metode Simple Additive Weighting (SAW) dan diimplementasikan dalam bentuk program yang menggunakan bahasa pemrograman PHP dan database $M y S Q L$ sehingga dapat mempermudah calon pembeli untuk mendapatkan informasi yang tepat. Metode penelitian ini digambarkan dengan menggunakan flowchart seperti gambar dibawah ini. 


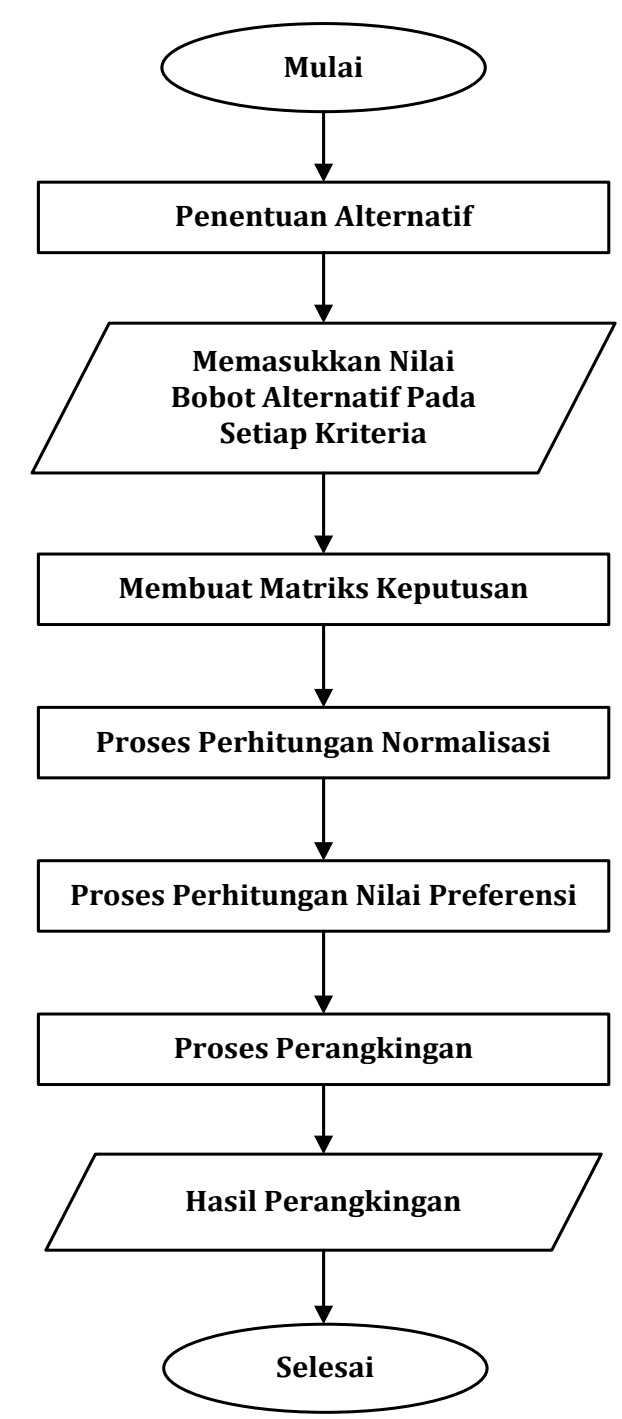

Gambar 1. Flowchart

Didalam melakukan penelitian pemilihan kacamata dengan menggunakan metode Simple Additive Weighting $(S A W)$ ini dilakukan beberapa tahapan sebagai berikut:

1. Penentuan alternatif, pada tahap ini ditentukan alternatif yang akan digunakan sebagai variabel input yaitu Mollucas Clip, Optika Lunet, dan Raito.

2. Memasukkan nilai bobot alternatif pada setiap kriteria, tahap ini memberikan nilai bobot untuk setiap kriteria dan memberikan penilaian pada setiap subkriteria, dapat dilihat pada Tabel 2 hingga Tabel 6.

3. Membuat matriks keputusan, tahap ini menentukan subkriteria pada masing-masing alternatif dapat dilihat pada Tabel 7.

4. Proses perhitungan normalisasi, tahap ini menormalisasikan nilai subkriteria dengan nilai bobot kriteria.

5. Proses perhitungan nilai preferensi, tahap ini mengkalikan nilai bobot kriteria dengan nilai $\mathrm{R}$ (matriks ternormalisasi).

6. Proses perangkingan, tahap ini menjumlahkan nilai preferensi pada masing-masing alternatif $\left(\mathrm{V}_{1}, \mathrm{~V}_{2}\right.$, dan $\left.\mathrm{V}_{3}\right)$.

7. Hasil perangkingan, tahap ini membandingkan nilai $V_{1}, V_{2}$, dan $V_{3}$ sehingga didapati nilai rangking terbesar. 


\subsection{Sistem Pendukung Keputusan}

Sistem Pendukung Keputusan atau Decision Support System (DSS) adalah sistem informasi interaktif yang menyediakan informasi, pemodelan, dan pemanipulasian data untuk memberikan solusi suatu masalah atau mengevaluasi suatu peluang. Hal yang diperlukan adalah data, interface yang mudah digunakan dan dapat menerapkan metode-metode Sistem Pendukung Keputusan itu sendiri sehingga memberikan hasil yang akurat dan berguna untuk mengelola data atau informasi yang akurat maupun tidak akurat berdasarkan kriteria tersebut.

Sistem Pendukung Keputusan adalah sistem pendukung berbasis komputer bagi para pengambil keputusan menajemen yang menangani masalah-masalah. Sistem Pendukung Keputusan (SPK) memadukan sumber daya intelektual dari individu dengan kapabilitas komputer yang meningkatkan kualitas keputusan.

\subsection{Metode Simple Additive Weighting (SAW)}

Metode Simple Additive Weghting (SAW) adalah metode yang digunakan untuk Multi Attribute Decision Making (MADM) yang digunakan untuk memberi keputusan. Menurut para ahli, metode Simple Additive Weighting (SAW) banyak dikenal dengan istilah metode terbobot yang terjumlah yang terdapat dari kesamaan alternatif pada setiap atribut.

Metode penjumlahan terbobot ini memiliki konsep dasar yang mencari penjumlahan terbobot dari rating kinerja pada setiap alternatif pada semua atribut. Metode ini juga direkomendasikan untuk menyelesaikan penyeleksian dalam berbagai proses. Metode Simple Additive Weghting (SAW) merupakan cara yang sering dipakai didalam mengambil tindakan yang memiliki banyak komponen, serta normalisasi matriks (x) ke dalam cakupan yang dapat dibandingkan dengan semua alternatif. Rumus untuk normalisasi tersebut dapat dilihat sebagai berikut:

$$
r_{i j}=\left\{\begin{array}{c}
\frac{\boldsymbol{X}_{i j}}{\boldsymbol{M a x} \boldsymbol{X}_{i j}} j i k a j \text { atribut keuntungan(benefit) } \\
\frac{\boldsymbol{M i n} \boldsymbol{X}_{i j}}{\boldsymbol{X}_{i j}} \text { jika } j \text { atribut biaya }(\text { cost })
\end{array}\right\}
$$

Keterangan :
$\operatorname{Max} \boldsymbol{X}_{i j} \quad$ : Nilai terbesar dari kriteria i
$\operatorname{Min} \boldsymbol{X}_{i j} \quad$ : Nilai terkecil dari kriteria i
$\boldsymbol{X}_{i j} \quad$ : Nilai atribut yang dimiliki dari setiap kriteria
Benefit : Jika nilai terbesar adalah yang terbaik
Cost : Jika nilai terkecil adalah yang terbaik

Dijelaskan bahwa $r_{i j}$ adalah suatu rating ternormalisasi dari alternatif $A_{i}$ pada atribut $C_{i j}$ $i=1,2, \ldots, n$. Untuk nilai preferensi pada setiap alternatif $\left(V_{i}\right)$ adalah sebagai berikut:

Keterangan:

$$
V_{i}=\sum_{j=1}^{n} W_{j} R_{i j}
$$

$\boldsymbol{V}_{\boldsymbol{i}} \quad$ : Ranking atau ketetapan untuk setiap alternatif

$\boldsymbol{W}_{\boldsymbol{j}}$ : Nilai bobot ranking atau ketetapan (dari setiap kriteria)

$\boldsymbol{r}_{\boldsymbol{i j}}:$ Nilai rating kinerja ternormalisasi

Dari nilai $V_{i}$ yang lebih besar mengindikasikan setiap alternatif $\left(A_{i}\right)$ lebih besar terpilih. Berikut ini adalah tahapan-tahapan menggunakan metode Simple Additive Weighting (SAW) sebagai berikut:

a. Dengan ditentukan kriteria yang akan dijadikan acuan dalam penentuan keputusan, yaitu $C_{i}$. 
b. Menentukan rating kecocokan setiap alternatif pada setiap kriteria.

c. Membuat matriks keputusan dari setiap kriteria $\left(C_{1}\right),\left(C_{2}\right),\left(C_{3}\right)$, dan $\left(C_{4}\right)$ lalu melakukan normalisasi pada matriks berdasarkan persamaan yang disesuaikan dengan jenis atribut lalu diperoleh matriks ternormalisasi.

Hasil yang didapat dari perhitungan yaitu penjumlahkan dari matrik yang sudah dikalikan dengan matrik ternormalisasi dengan bobot vektor lalu dihasilkan nilai terbesar yang terpilih sebagai alternatif terbaik $\left(A_{1}\right)$ sebagai keputusan yang diinginkan.

\section{HASIL DAN PEMBAHASAN}

Menerapkan metode Simple Additive Weighting (SAW) pada kriteria dan alternatif kacamata dengan langkah-langkah sebagai berikut:

\subsection{Analisa Kebutuhan}

1. Data Alternatif

Data yang ditentukan sebagai alternatif kacamata sebagai berikut:

Tabel 1. Alternatif

\begin{tabular}{|c|c|}
\hline Id Alternatif & Alternatif \\
\hline A001 & Mollucas Clip \\
\hline A002 & Optika Lunet \\
\hline A003 & Raito \\
\hline
\end{tabular}

2. Data Nilai Bobot Kriteria

Data nilai bobot kriteria yang ditentukan sebagai berikut:

Tabel 2. Nilai Bobot Kriteria

\begin{tabular}{|c|c|}
\hline Kriteria & Bobot \\
\hline Lensa & 0,40 \\
\hline Warna Frame & 0,20 \\
\hline Harga & 0,30 \\
\hline Merek & 0,10 \\
\hline
\end{tabular}

3. Penilaian Kriteria Lensa $\left(C_{1}\right)$

Nilai subkriteria pada kriteria lensa adalah sebagai berikut:

Tabel 3. Kriteria Lensa

\begin{tabular}{|c|c|}
\hline Nilai & Lensa \\
\hline 40 & Kaca \\
\hline 30 & Mika \\
\hline
\end{tabular}

4. Penilaian Kriteria Warna Frame $\left(C_{2}\right)$

Nilai subkriteria pada kriteria warna frame adalah sebagai berikut:

Tabel 4. Kriteria Warna Frame

\begin{tabular}{|c|c|}
\hline Nilai & Warna Frame \\
\hline 30 & Sangat Menarik \\
\hline 20 & Menarik \\
\hline 10 & Tidak Menarik \\
\hline
\end{tabular}


5. Penilaian Kriteria Harga $\left(C_{3}\right)$

Nilai subkriteria pada kriteria harga adalah sebagai berikut:

Tabel 5. Kriteria Harga

\begin{tabular}{|c|c|}
\hline Nilai & Harga \\
\hline 30 & $<500.000$ \\
\hline 20 & $600.000-1.000 .000$ \\
\hline 10 & $>1.000 .000$ \\
\hline
\end{tabular}

6. Penilaian Kriteria Merek $\left(C_{4}\right)$

Nilai subkriteria pada kriteria merek adalah sebagai berikut:

Tabel 6. Kriteria Merek

\begin{tabular}{|c|c|}
\hline Nilai & Merek \\
\hline 20 & Terkenal \\
\hline 10 & Biasa \\
\hline
\end{tabular}

Dari keempat kriteria tersebut, kriteria $\left(C_{1}\right),\left(C_{2}\right)$, dan $\left(C_{4}\right)$ merupakan kriteria benefit karena dengan semakin besar nilai maka akan semakin baik, sedangkan kriteria $\left(C_{3}\right)$ merupakan kriteria cost karena dengan semakin kecil nilai maka akan semakin baik, kriteria dan alternatif diolah menggunakan metode Simple Additive Weghting (SAW) untuk menghasilkan rekomendasi pemilihan kacamata terbaik. Adapun dibawah ini perhitungan metode Simple Additive Weighting (SAW) yang dibuat manual untuk pemilihan kacamata.

\subsection{Penerapan Metode}

1. Membuat Matriks Keputusan

Tabel 7 dibawah ini adalah subkriteria dari setiap kriteria pada masing-masing alternatif sebagai berikut:

Tabel 7. Data Alternatif

\begin{tabular}{|c|c|c|c|c|}
\hline Alternatif/Kriteria & $\boldsymbol{C}_{\mathbf{1}}$ & $\boldsymbol{C}_{\mathbf{2}}$ & $\boldsymbol{C}_{\mathbf{3}}$ & $\boldsymbol{C}_{\boldsymbol{4}}$ \\
\hline Mollucas Clip & Kaca & Menarik & 1.500 .000 & Terkenal \\
\hline Optika Lunet & Kaca & Menarik & 300.000 & Biasa \\
\hline Raito & Kaca & Tidak Menarik & 1.000 .000 & Biasa \\
\hline
\end{tabular}

Dari tabel diatas diperoleh matrik keputusan (R) sebagai berikut:

$$
X=\left(\begin{array}{llll}
40 & 20 & 10 & 20 \\
40 & 20 & 30 & 10 \\
40 & 10 & 20 & 10
\end{array}\right)
$$

2. Membuat Matrik Ternormalisasi

Normalisasi matrik yang akan dibuat dengan cara menghitung nilai dari rating setiap kriteria dan menghasilkan matrik ternormalisasi sebagai berikut: 


\section{Proses Perankingan}

$$
R=\left(\begin{array}{cccc}
1 & 1 & 0,33 & 1 \\
1 & 1 & 1 & 0,50 \\
1 & 0,50 & 0,67 & 0,50
\end{array}\right)
$$

Dalam pemilihan kacamata dipilih bobot sebagai berikut: $W=[0,40 ; 0,20 ; 0,30 ; 0,10]$. Hasil perankingan yang diperoleh dari penerapan metode Simple Additive Weighting (SAW) adalah sebagai berikut:

$$
\begin{array}{ll}
\mathrm{V}_{1}=(0,40 * 1)+(0,20 * 1)+(0,30 * 0,33)+(0,10 * 1) & =0,80 \\
V_{2}=(0,40 * 1)+(0,20 * 1)+(0,30 * 1)+(0,10 * 0,50) & =0,95 \\
V_{3}=(0,40 * 1)+(0,20 * 0,50)+(0,30 * 0,67)+(0,10 * 0,50) & =0,75
\end{array}
$$

Nilai terbesar adalah $\mathbf{0 , 9 5}$ yaitu $\mathrm{V}_{2}$ sehingga alternatif tersebut adalah alternatif yang terpilih sebagai alternatif terbaik. Oleh karena itu Optika Lunet terpilih sebagai kacamata terbaik dan direkomendasikan kepada pembeli.

\subsection{Implementasi Program}

1. Beranda

Beranda merupakan halaman awal yang pertama kali muncul ketika diakses dan terdapat beberapa menu yaitu input data, view data, dan perhitungan Metode Simple Additive Weghting (SAW).

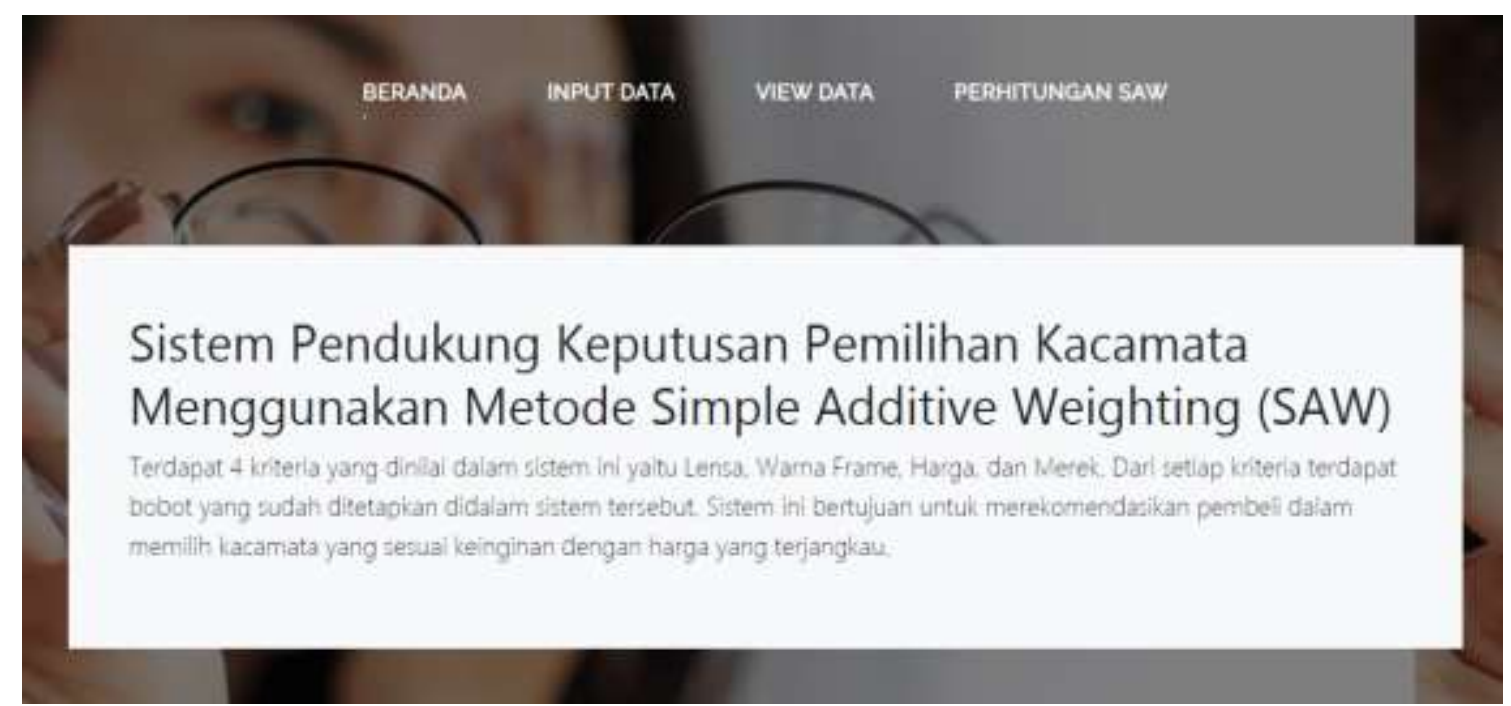

Gambar 2. Beranda

\section{Matriks Keputusan}

Halaman ini dapat memasukkan data nilai matriks keputusan berdasarkan rating kecocokan pada masing-masing kriteria setiap alternatif. 


\begin{tabular}{|c|c|c|c|c|c|}
\hline \multicolumn{2}{|c|}{ BERANDA } & INPUT DATA & VIEW DATA & \multicolumn{2}{|c|}{ HITUNG SAW } \\
\hline Matriks Keputusan & \multicolumn{2}{|c|}{ Nilai Bobot } & \multicolumn{2}{|c|}{ Normalisasi } & Perangkingan \\
\hline Id Alternatif & Lensa & Warna & & Harga & Merek \\
\hline $\mathrm{A} 001$ & 40 & 20 & & 10 & 20 \\
\hline $\mathrm{A} 002$ & 40 & 20 & & 30 & 10 \\
\hline $\mathrm{A} 003$ & 40 & 10 & & 20 & 10 \\
\hline
\end{tabular}

Gambar 3. Matriks Keputusan

3. Nilai Bobot

Halaman ini dapat memasukkan data nilai bobot kriteria untuk dapat dihitung nilai matriks ternormalisasinya.

BERANDA INPUTDATA VIEW DATA HITUNGSAW

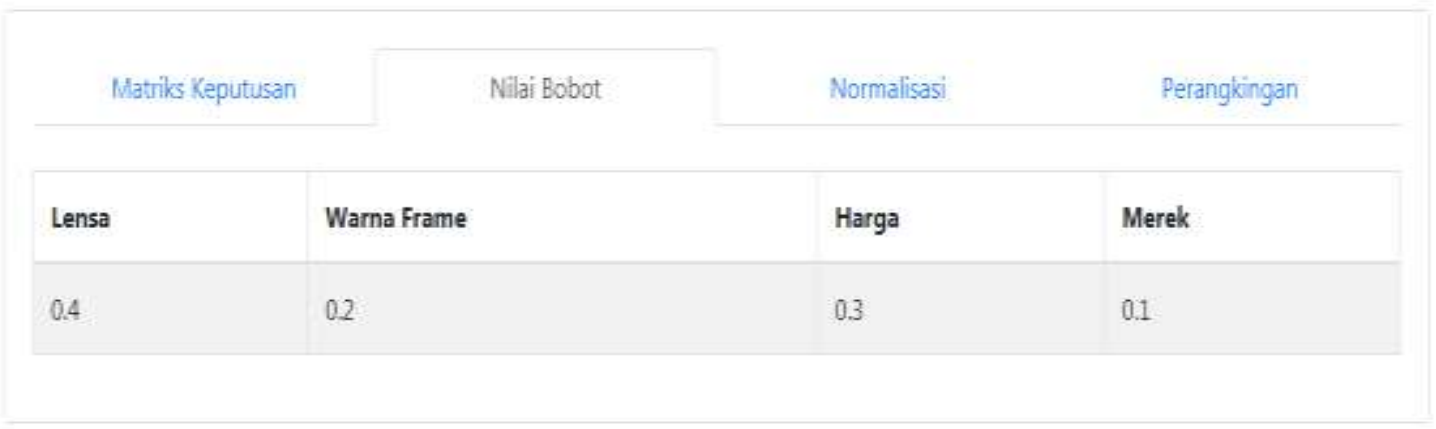

Gambar 4. Nilai Bobot

4. Normalisasi

Halaman normalisasi ini menampilkan kalkulasi metode Simple Additive Weghting (SAW) dari matriks ternormalisasi. 


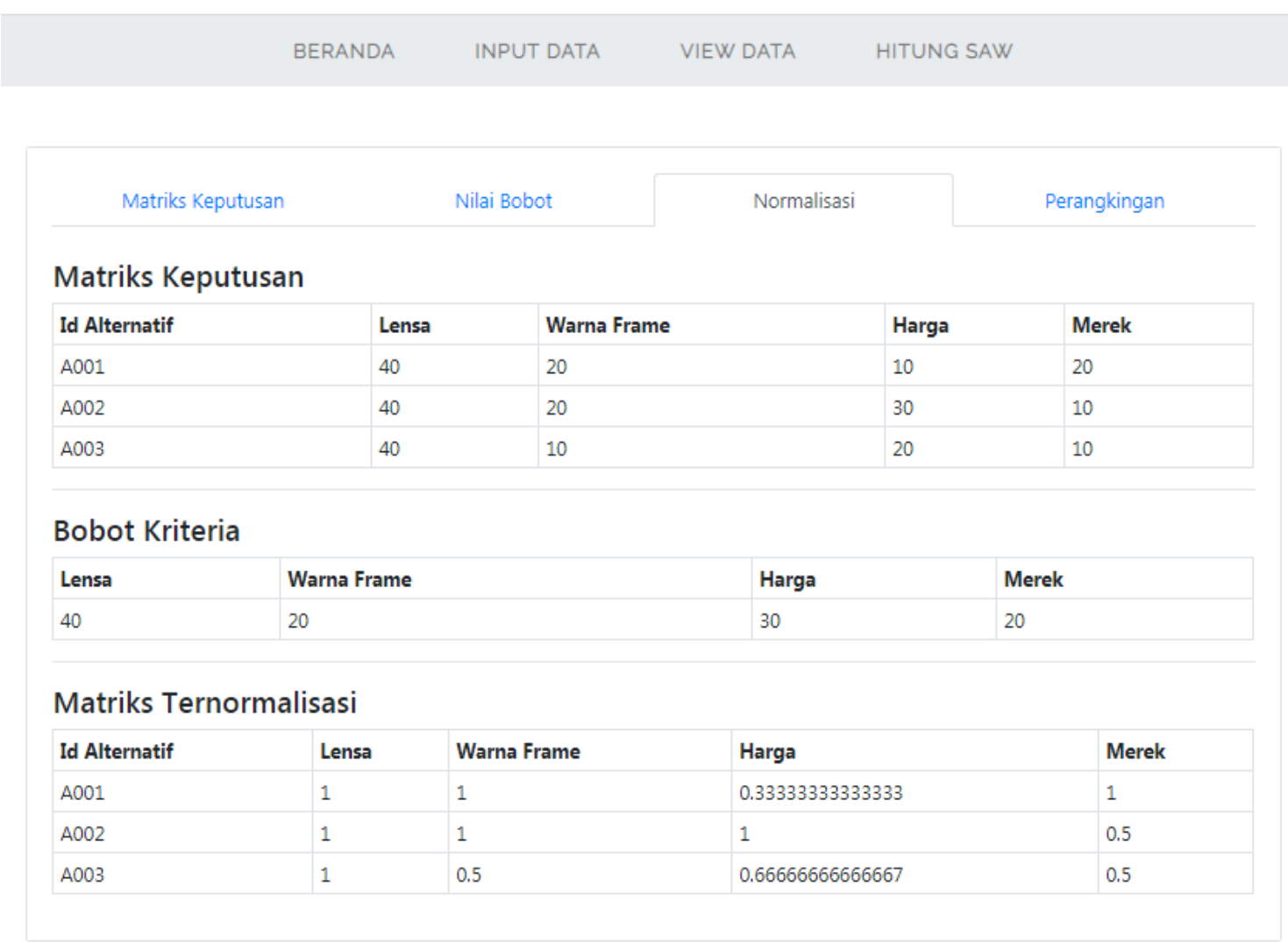

\section{Gambar 5. Normalisasi}

\section{Perankingan}

Halaman ini dapat dilihat perankingan yang dihasilkan dari perhitungan metode Simple Additive Weighting $(S A W)$ dan menampilkan alternatif terbaik berdasarkan nilai preferensi terbesar.

BERANDA INPUT DATA VIEW DATA HITUNG SAW

\begin{tabular}{|c|c|c|c|c|c|c|}
\hline \multicolumn{2}{|c|}{ Matriks Keputusan } & Nilai Bobot & \multicolumn{3}{|c|}{ Normalisasi } & rangkingan \\
\hline Id Alternatif & Lensa & Warna Frame & Harga & Merek & Total Nilai & Rangking \\
\hline $\mathrm{A} 002$ & 0.4 & 0.2 & 0.3 & 0.05 & 0.95 & 1 \\
\hline $\mathrm{A} 001$ & 0.4 & 0.2 & 0.1 & 0.1 & 0.8 & 2 \\
\hline $\mathrm{A} 003$ & 0.4 & 0.1 & 0.2 & 0.05 & 0.75 & 3 \\
\hline
\end{tabular}

Gambar 6. Perankingan 


\section{KESIMPULAN}

Pemilihan kacamata dan menerapkan metode Simple Additive Weghting (SAW) pada penelitian ini ditentukan oleh beberapa kriteria yaitu lensa, warna frame, harga, dan merek. Hasil penerapan metode Simple Additive Weighting (SAW) dan implementasi pada program memberikan hasil yang sama untuk merekomendasikan kacamata yaitu Optika Lunet dengan nilai preferensi 0,95. Jika pembeli memilih kacamata dengan lensa kaca, warna frame menarik, harga yang terjangkau, tetapi dengan merek biasa sudah mendapatkan kacamata terbaik, dalam hal ini kacamata Optika Lunet sangat direkomendasikan.

\section{SARAN}

Sistem Pendukung Keputusan pemilihan kacamata ini dapat dikembangkan dengan menerapkan beberapa metode selain Simple Additive Weighting (SAW) seperti menggunakan Metode Weighted Product (WP), Metode Analitycal Hierarchy Process (AHP), Metode Technique For Others Referenceby Similarity to Ideal Solution (TOPSIS), dan metode lainnya yang dapat membantu menyelesaikan masalah. Dapat juga dilakukan perbandingan dengan beberapa metode diatas sehingga menghasilkan alternatif yang lebih tepat dan akurasi dari masing-masing alternatif.

\section{DAFTAR PUSTAKA}

[1] Yustina, N. (2013). Sistem Pendukung Keputusan Pemilihan Lensa Kontak Bagi Penderita Kelainan Refraksi Mata Menggunakan Metode Simple Additive Weighting (Doctoral dissertation, Universitas Brawijaya).

[2] Turban, E., Aronson, J. E., \& Liang, T. P. (2005). Decision Support System and Intelegent System.

[3] Adlhiyah, L., \& Mustafidah, H. (2017). Sistem Pendukung Keputusan Pemilihan Lensa Kontak (Softlens) Menggunakan Metode Simple Additive Weighting (SAW). JUITA: Jurnal Informatika, 4(2), 105-115.

[4] Novida, E., \& Sunandar, H. (2018). Sistem pendukung keputusan pemilihan produk lensa kacamata menggunakan metode promethee ii. Pelita Informatika: Informasi dan Informatika, 6(3), 325-332.

[5] Puspita, K., \& Putra, P. H. (2015, February). Penerapan Metode Simple Additive Weighting (SAW) Dalam Menentukan Pendirian Lokasi Gramedia Di Sumatera Utara. In Seminar Nasional Teknologi Informasi Dan Multimedia, ISSN (pp. 2302-3805).

[6] Tanjung, D. Y. H., \& Adawiyah, R. (2018, August). Optimizing Selection of Decision Support System with Fuzzy Simple Additive Weighting. In 2018 6th International Conference on Cyber and IT Service Management (CITSM) (pp. 1-4). IEEE.

[7] Verina, W., Andrian, Y., \& Rahmad, I. F. (2015). Penerapan Metode Fuzzy SAW untuk Penerimaan Pegawai Baru (Studi Kasus: STMIK Potensi Utama). Sisfotenika, 5(1), 60-70. 